\title{
The Effect of Protein Expression of Streptococcus pneumoniae by Blood
}

\author{
Song-Mee Bae ${ }^{1}$, Sun-Mi Yeon ${ }^{2}$, Tong-Soo Kim ${ }^{2}$ and Kwang-Jun Lee ${ }^{1, *}$ \\ ${ }^{1}$ Division of Bacterial Respiratory Infections, Center for Infectious Disease, \\ ${ }^{2}$ Lab. of Pathogenic Proteomics, Center for Immunology \& Pathology, National Institute of Health, \\ Korea Center for Diseases control and Prevention, 5 Nokbun-Dong, Eunpyung-Ku, Seoul, 122-701, Korea
}

Received 5 January 2006, Accepted 20 July 2006

\begin{abstract}
During infection, the common respiratory tract pathogen Streptococcus pneumoniae encounters several environmental conditions, such as upper respiratory tract, lung tissue, and blood stream, etc. In this study, we examined the effects of blood on $S$. pneumoniae protein expression using a combination of highly sensitive 2-dimensional electrophoresis (DE) and MALDI-TOF MS and/or LC/ ESI-MS/MS. A comparison of expression profiles between the growth in THY medium and THY supplemented with blood allowed us to identify 7 spots, which increased or decreased two times or more compared with the control group: tyrosyl-tRNA synthetase, lactate oxidase, glutamylaminopeptidase, L-lactate dehydrogenase, cysteine synthase, ribose-phosphate pyrophosphokinase, and orotate phosphoribosyltransferase. This global approach can provide a better understanding of $S$. pneumoniae adaptation to its human host and a clue for its pathogenicity.
\end{abstract}

Keywords: Blood, Streptococcus pneumoniae, Two-dimensional gel electrophoresis

\section{Introduction}

Streptococcus pneumoniae (Pneumococci) is a major pathogen causing very serious and often fatal diseases such as meningitis, bacteremia, sepsis, or pneumonia and less serious diseases such as sinusitis or otitis media (Schuchat et al., 1997; Tuomanen, 1999). This pathogen commonly colonizes the nasopharynx asymptomatically in healthy children and adults and is also a transient commensal, colonizing upper respiratory tract in 40\% of humans (Dinieal et al., 2000; Hoskins et al., 2001; Nakamura et al., 2004). The breadth of invasive diseases

* To whom correspondence should be addressed.

Tel: 82-2-380-1474; Fax: 82-2-385-8043

E-mail: Kwangjun@yahoo.com caused by $S$. pneumoniae implies that this microorganism has to adapt to the environmental conditions encountered at several sites of infection (Charpentier et al., 2000).

During infection, invasive strain of $S$. pneumoniae penetrates into the blood stream and undergoes spontaneous phase variation switching from transparent to opaque colony morphotype. The switch of phenotype might regulate the protein expression and improve survival in the bloodstream of host (Tuomanen, 1999; Novak et al., 1999; Novak et al., 2000). Understanding the mechanisms regulating the expression of genes in response to environmental changes is great important for comprehending the host-pathogen interaction during infection.

In this study, we established $S$. pneumoniae proteome and examined the effects of blood on $S$. pneumoniae protein expression using a combination of highly sensitive 2-dimensional electrophoresis (DE) and matrix-assisted laser desorption-/ ionization-time of flight mass spectrometry (MALDI-TOF MS) and/or liquid chromatography/electrospray ionization tandem mass spectrometry (LC/ESI-MS/MS).

\section{Materials and Methods}

Bacterial strain and growth conditions. A virulent $S$. pneumoniae D39 strain (capsular type 2) was routinely maintained on blood agar plate supplemented with $5 \%(\mathrm{v} / \mathrm{v})$ defibrinated sheep blood (KOMED Co. Ltd, Korea). For a reference map, S. pneumoniae was grown in Todd-Hewitt broth supplemented with $0.5 \%$ yeast extract (THY) in $5 \% \mathrm{CO}_{2}$ at $37^{\circ} \mathrm{C}$. Bacteria growth was monitored by measuring the absorbance at $600 \mathrm{~nm}$ using a Beckman DU 530 spectrophotometer. For compare the effect of blood, S. pneumoniae was inoculated on the Todd-Hewitt agar plate supplemented with $5 \%$ sheep blood (THA-BA plate) or Todd-Hewitt agar plate (THA plate) supplemented with 5,000 U catalase (SIGMA) per plate, respectively. All cultures were incubated in a controlled atmosphere chamber $\left(37^{\circ} \mathrm{C}, 5 \% \mathrm{CO}_{2}\right.$; Bellco) for $16 \mathrm{~h}$. The resulting serial passages of cultures were avoided and stocks were maintained at $-70^{\circ} \mathrm{C}$ until they were required for further experiments. 
Protein extraction for 2-DE. Colonies grown on each plate were washed twice in $30 \mathrm{~mL}$ of prechilled phosphate buffered saline (0.01 M PBS, pH 7.4). Bacteria were resuspended in an appropriate volume of TE buffer (10 mM Tris, $1 \mathrm{mM}$ ethylenediaminetetraacetic acid, $\mathrm{pH}$ 8.0) and sonicated six times for $30 \mathrm{~s}$ each, using a sonicator model XL (Heat Systems). The cell lysates were treated with $100 \mu \mathrm{g} / \mathrm{mL}$ DNase I and $50 \mu \mathrm{g} / \mathrm{mL}$ RNase A on ice for $30 \mathrm{~min}$ and clarified by centrifugation at $12,000 \times g$ for $10 \mathrm{~min}$ at $4^{\circ} \mathrm{C}$. The protein concentration was measured using the Bradford assay (BioRad). The resulting supernatants were stored in aliquots at $-70^{\circ} \mathrm{C}$ until they were required for further experiments.

2-DE and image analysis. Approximately $80 \mu \mathrm{g}$ (for silver staining) of protein samples was brought to a final volume of 500 $\mu \mathrm{L}$ with rehydration solution containing $7 \mathrm{M}$ urea, $2 \mathrm{M}$ thiourea, 4\% 3-[(3-cholamidopropyl) dimethyl-amonio]-1-propanesulfonate (CHAPS), $40 \mathrm{mM}$ Tris- $\mathrm{Cl}, 0.5 \%$ immobilized $\mathrm{pH}$ gradient (IPG) buffer, $2 \mathrm{mM}$ tributyl phosphine (TBP), and $0.002 \%$ bromophenol blue (BPB) and applied on $18 \mathrm{~cm}$ IPG strips (4-7 linear, Amersham Pharmacia Biotech) by in-gel rehydration for $16 \mathrm{~h}$ at $20^{\circ} \mathrm{C}$ (Rabilloud, 1996; Herbert et al., 1998). After rehydration, isoelectric focusing (IEF) was carried out using the IPGphore Isoelectric Focusing System (Amersham pharmacia Biotech). Proteins were focused at $500 \mathrm{~V}$ for $1 \mathrm{~h}, 1000 \mathrm{~V}$ for $1 \mathrm{~h}$, and then $8000 \mathrm{~V}$ for $4 \mathrm{~h}$. The IPG strips were then equilibrated in $50 \mathrm{mM}$ Tris- $\mathrm{Cl}, 6 \mathrm{M}$ urea, $30 \%$ glycerol, $2 \%$ sodium dodecyl sulfate (SDS), $1 \%$ BPB, and $5 \mathrm{mM}$ TBP. Protein separation in the second dimension was performed in $10 \%$ SDS-polyacrylamide gels in a Protean II xi electrophoresis kit (Bio-Rad). Protein spots were visualized by silver staining (Amersham pharmacia Biotech) (Neuhoff, 1988; Heukeshoven et al., 1991). The abundance of protein spots on the 2-DE gels was analyzed by scanning the spots with a PowerLook 1100 scanner (UMAX, Taiwan). The intensity of each protein spot was measured using Progenesis software V.1.01 (PerkinElmer, nonlinear Dynamics). For the same sample, 2-DE was repeated at least five times to confirm reproducibility.

\section{Protein identification}

MALDI-TOF. Following the selection of the spots of interest, they were manually excised from the stained 2-DE gels and subjected to in-gel tryptic digestion (Dowds et al., 1991). The MALDI-TOF spectra of the peptides were obtained with a Voyager-DE STR Biospectrometry Workstation mass spectrometer (PE Biosystems) by delayed extraction in reflector mode. The peptide mass fingerprints obtained for each protein digestion were analyzed using the NCBI nonredundant protein database against $S$. pneumoniae with MASCOT software (Matrix Science, London, UK, at http:// www.matrixscience.com). Criteria for positive identification of the proteins were set as follows: (1) at least four matched peptide masses, (2) mass accuracy of 50 ppm or higher, (3) 50 scores in MASCOT, and (4) $10 \%$ of sequence coverage. All proteins were identified within expected molecular weights, and $\mathrm{pI}$ ranges were based on their positions in the gels.

LC/ESI-MS/MS. For LC/ESI-MS/MS analysis of tryptic-digested peptides, protein spots of interest were excised and digested in-gel with sequencing-grade and modified trypsin (Promega) (Dowds et al., 1991; Herbert et al., 1998). The digested peptides were separated and analyzed using reversed-phase capillary HPLC directly coupled to a Finnigan LCQ ion trap mass spectrometer (LC MS/MS). Peptides were bound and preconcentrated in the trapping column using $5 \%(\mathrm{v} / \mathrm{v})$ acetonitrile in $0.1 \%(\mathrm{v} / \mathrm{v})$ formic acid. The eluting gradient was $5 \%-80 \%(\mathrm{v} / \mathrm{v})$ acetonitrile in $0.5 \%(\mathrm{v} / \mathrm{v})$ for $50 \mathrm{~min}$ at a flow rate of $0.15 \mu \mathrm{L} / \mathrm{min}$. Eluent from the capillary column was directly sprayed into the ion trap mass spectrometer. All data were collected in centroid mode using the "triple play" mode: a full mass scan at a mass range of 395-2000 Da (m/z), determination of the charge state of an ion on zoom scan, and then acquisition of the MS/MS spectrum of each ion on a full MS/MS scan, whose collision energy was preset at a value of $55 \%$. Sequences of noninterpreted MS/MS spectra were identified by correlation with peptide sequences present in the MSDB, OWL or NCBI nonredundant protein databases using MASCOT search program (http://www.matrixscience.com).

\section{Results}

S. pneumoniae D39 proteome map. For the reference proteome map, $S$. pneumoniae D39 was grown to exponential growth phase $\left(\mathrm{OD}_{600 \mathrm{~nm}}\right.$ of 0.3$)$ in THY broth, and $80 \mu \mathrm{g}$ of protein was separated on the IPG strips with a $\mathrm{p} I$ range of $4-7$ and $10 \%$ SDS-PAGE. A total of 466 protein spots were detected in the $\mathrm{p} I$ range 4 to 7 , as shown in Fig. 1, and then, 49 spots were identified by MALDI-TOF MS or LC-ESI MS/MS (Table 1). Interestingly, several proteins are expressed the multiple spots, in most cases two or three forms, exhibited variability in $\mathrm{p} I$ values (horizontal spot patterns).

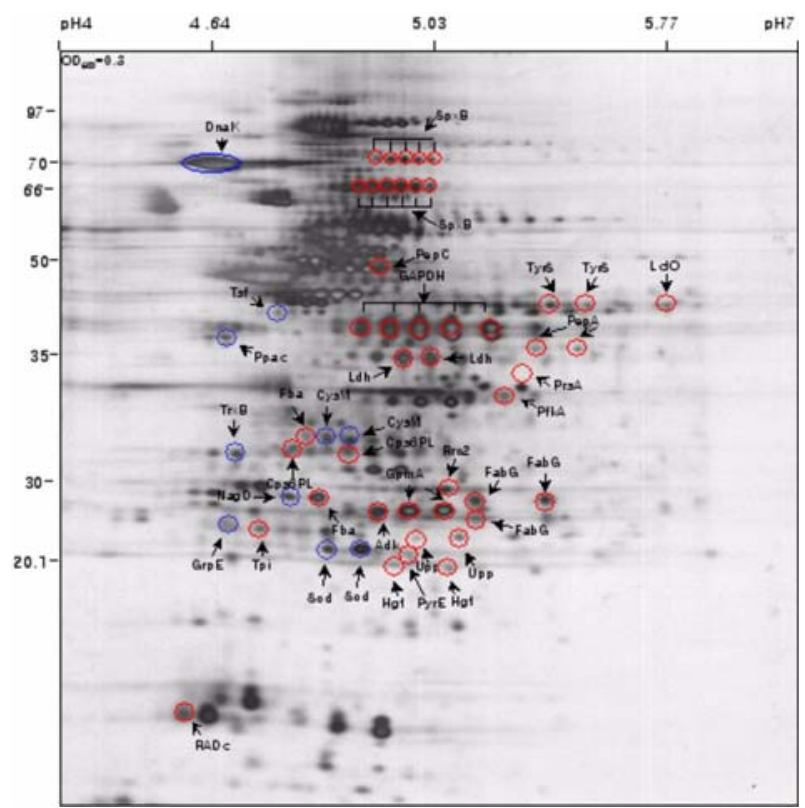

Fig. 1. The reference map of S. pneumoniae D39 at an $\mathrm{OD}_{600 \mathrm{~nm}}$ of 0.3 in THY broth. Extracted proteins were separated by isoelectric focusing in the $\mathrm{p} I$ range of 4 to 7 in the first dimension $(18 \mathrm{~cm})$ and by $10 \%$ SDS-PAGE in the second dimension. Resolved proteins were visualized by silver staining. 
Table 1. Summary of identified pneumococal 49 protein spots in the reference map

\begin{tabular}{|c|c|c|c|c|c|c|}
\hline No. & Identified protein & $\begin{array}{c}\text { Top } \\
\text { score }\end{array}$ & $\begin{array}{l}\text { Matched } \\
\text { peptides }\end{array}$ & $\begin{array}{c}\text { Sequence } \\
\text { coverage } \\
(\%)\end{array}$ & $\begin{array}{l}\text { Theoretical } \\
\mathrm{Mr}(\mathrm{KDa}) / \mathrm{pI}\end{array}$ & $\begin{array}{c}\text { Measured } \\
\mathrm{Mr}(\mathrm{KDa}) / \mathrm{p}\end{array}$ \\
\hline 1 & Fructose-bisphosphate aldolase (Fba) & 62 & 5 & 31 & $31.4 / 5.0$ & $33.4 / 5.0$ \\
\hline 2 & Cysteine synthase & 466 & 21 & 34 & $32 / 5.0$ & $36 / 5.0$ \\
\hline 3 & 3-oxoacyl-[acyl-carrier protein] reductase $(\mathrm{FabG})$ & 55 & 5 & 23 & $22.9 / 5.31$ & $28 / 5.5$ \\
\hline 4 & 3-oxoacyl-[acyl-carrier protein] reductase (FabG) & 124 & 9 & 49 & $25.7 / 5.49$ & $28 / 5.5$ \\
\hline 5 & Uracil phosphate dehydrogenase (Upp) & 56 & 5 & 37 & $22.9 / 5.42$ & $29 / 5.5$ \\
\hline 6 & Uracil phosphate dehydrogenase (Upp) & 66 & 8 & 44 & $22.9 / 5.42$ & $26 / 5.4$ \\
\hline 7 & Glyceraldehyde 3-phosphate dehydrogenase (GAPDH) & 47 & 6 & 14 & $38.7 / 5.78$ & $37 / 5.2$ \\
\hline 8 & Glyceraldehyde 3-phosphate dehydrogenase (GAPDH) & 58 & 8 & 15 & $32.4 / 5.16$ & $37 / 5.3$ \\
\hline 9 & Glyceraldehyde 3-phosphate dehydrogenase (GAPDH) & 60 & 6 & 20 & $35.8 / 5.29$ & $37 / 5.4$ \\
\hline 10 & Glyceraldehyde 3-phosphate dehydrogenase (GAPDH) & 95 & 9 & 30 & $35.8 / 5.29$ & $37 / 5.5$ \\
\hline 11 & Pyruvate oxidase $(\mathrm{SpxB})$ & 73 & 11 & 25 & $65.2 / 5.03$ & $80 / 5.4$ \\
\hline 12 & Lactate dehydrogenase (Ldh) & 70 & 9 & 28 & $35 / 5.02$ & $43 / 5.5$ \\
\hline 13 & $\mathrm{ABC}$ transporter, $\mathrm{ATP}-$ binding protein $(\mathrm{ABC}-\mathrm{NBD})$ & 81 & 6 & 36 & $28.4 / 4.67$ & $28 / 4.5$ \\
\hline 14 & Heat shock protein GrpE & 163 & 3 & 7 & $20 / 4.6$ & $25 / 4.3$ \\
\hline 15 & Cysteine synthase & 431 & 14 & 27 & $32 / 5.0$ & $36 / 5.2$ \\
\hline 16 & Thioredoxin reductase & 171 & 5 & 12 & $33 / 4.8$ & $31 / 4.2$ \\
\hline 17 & Fructose-bisphosphate aldolase (Fba) & 62 & 6 & 33 & $31.4 / 5.0$ & $31 / 5.2$ \\
\hline 18 & Adenylate kinase (Adk) & 78 & 8 & 41 & $23.6 / 4.96$ & $28 / 5.0$ \\
\hline 19 & Manganese co-factored superoxide dismutase & 353 & 14 & 31 & $22 / 5.0$ & $24 / 4.9$ \\
\hline 20 & rRNA(adenine-N6)-methyltransferase (RADc) & 40 & 6 & 24 & $28.8 / 9.8$ & $19 / 4.2$ \\
\hline 21 & Pyruvate oxidase (SpxB) & 75 & 7 & 35 & $41.6 / 5.77$ & $60 / 5.2$ \\
\hline 22 & Aminopeptidase C (PepC) & 97 & 13 & 33 & $50.2 / 5.09$ & $50 / 5.2$ \\
\hline 23 & Tyrosyl-tRNA synthetase (TyrS) & 99 & 10 & 29 & $47.5 / 5.46$ & $44 / 5.4$ \\
\hline 24 & Tyrosyl-tRNA synthetase (TyrS) & 56 & 7 & 29 & $47.5 / 5.4$ & $64.4 / 5.5$ \\
\hline 25 & Glutamyl-aminopeptidase (PepA) & 71 & 7 & 34 & $38.2 / 5.46$ & $40 / 6$ \\
\hline 26 & L-lactate dehydrogenase (Ldh) & 93 & 8 & 28 & $35.3 / 5.09$ & $35 / 5.1$ \\
\hline 27 & 6-phosphofructokinase (PfkA) & 78 & 8 & 34 & $35.3 / 5.33$ & $37 / 5.5$ \\
\hline 28 & Glucose-1-phosphate thymidylytransferase (Cps6PL) & 131 & 14 & 50 & $32.3 / 4.79$ & $32 / 4.6$ \\
\hline 29 & Glucose-1-phosphate thymidylytransferase (Cps6PL) & 84 & 9 & 37 & $32.3 / 4.79$ & $32 / 4.8$ \\
\hline 30 & $\mathrm{~N}$-acetyl-glucosamine metabolism (NagD) & 373 & 8 & 34 & $28 / 4.7$ & $30 / 4.8$ \\
\hline 31 & Glucose-1-phosphate thymidylytransferase (Cps6PL) & 65 & 6 & 35 & $26.7 / 4.97$ & $29 / 5.2$ \\
\hline 32 & Cysteine synthase (CysM) & 120 & 9 & 33 & $32 / 4.9$ & $33 / 5.0$ \\
\hline 33 & Orotate phosphoribosyltransferase (PyrE) & 74 & 6 & 31 & $22 / 5.0$ & $23 / 5.0$ \\
\hline 34 & Lactate oxidase $(\mathrm{LctO})$ & 75 & 7 & 35 & $41.6 / 5.77$ & $45 / 6.4$ \\
\hline 35 & Glutamyl-aminopeptidase (PepA) & 108 & 10 & 50 & $38.2 / 5.46$ & $40 / 5.9$ \\
\hline 36 & DNA-binding response regulator $(\mathrm{Rr} 02)$ & 65 & 6 & 351 & $35 / 5.02$ & $40 / 4.9$ \\
\hline 37 & L-lactate dehydrogenase (Ldh) & 73 & 6 & 24 & $35.3 / 5.09$ & $40 / 5.1$ \\
\hline 38 & Ribose-phosphate pyrophosphokinase (PrsA) & 94 & 9 & 38 & $35.6 / 5.68$ & $38 / 5.6$ \\
\hline 39 & Glucosamine-6-phosphate isomerase (NagB) & 78 & 5 & 33 & $25.5 / 4.56$ & $31 / 4.2$ \\
\hline 40 & Glucosamine-6-phosphate isomerase (NagB) & 42 & 4 & 24 & $25.5 / 4.56$ & $31 / 4.3$ \\
\hline 41 & Phosphoglycerate mutase (GpmA) & 165 & 11 & 58 & $26 / 5.14$ & $28 / 5.2$ \\
\hline 42 & Phosphoglycerate mutase (GpmA) & 186 & 13 & 62 & $26 / 5.14$ & $28 / 5.3$ \\
\hline 43 & Triosephosphate isomerase (Tpi) & 62 & 7 & 27 & $26.8 / 4.75$ & $27 / 4.8$ \\
\hline 44 & Hypoxanthine phosphoriosyltransferase (Hgt) & 58 & 5 & 26 & $20.3 / 5.26$ & $24 / 5.2$ \\
\hline 45 & Hypoxanthine phosphoriosyltransferase (Hgt) & 66 & 7 & 31 & $20.3 / 5.26$ & $24 / 5.3$ \\
\hline 46 & Heat shock protein 70 (DnaK) & 714 & 31 & 24 & $65 / 4.6$ & $70 / 4.5$ \\
\hline 47 & Manganese-co-factored superoxide dismutase & 161 & 2 & 14 & $22 / 5.0$ & $25 / 4.8$ \\
\hline 48 & Elongation factor TS & 98 & 3 & 9 & $37 / 4.8$ & $40 / 4.8$ \\
\hline 49 & Manganese-dependent inorganic pyrophosphatase (Ppac) & 484 & 20 & 27 & $33 / 4.6$ & $40 / 4.5$ \\
\hline
\end{tabular}



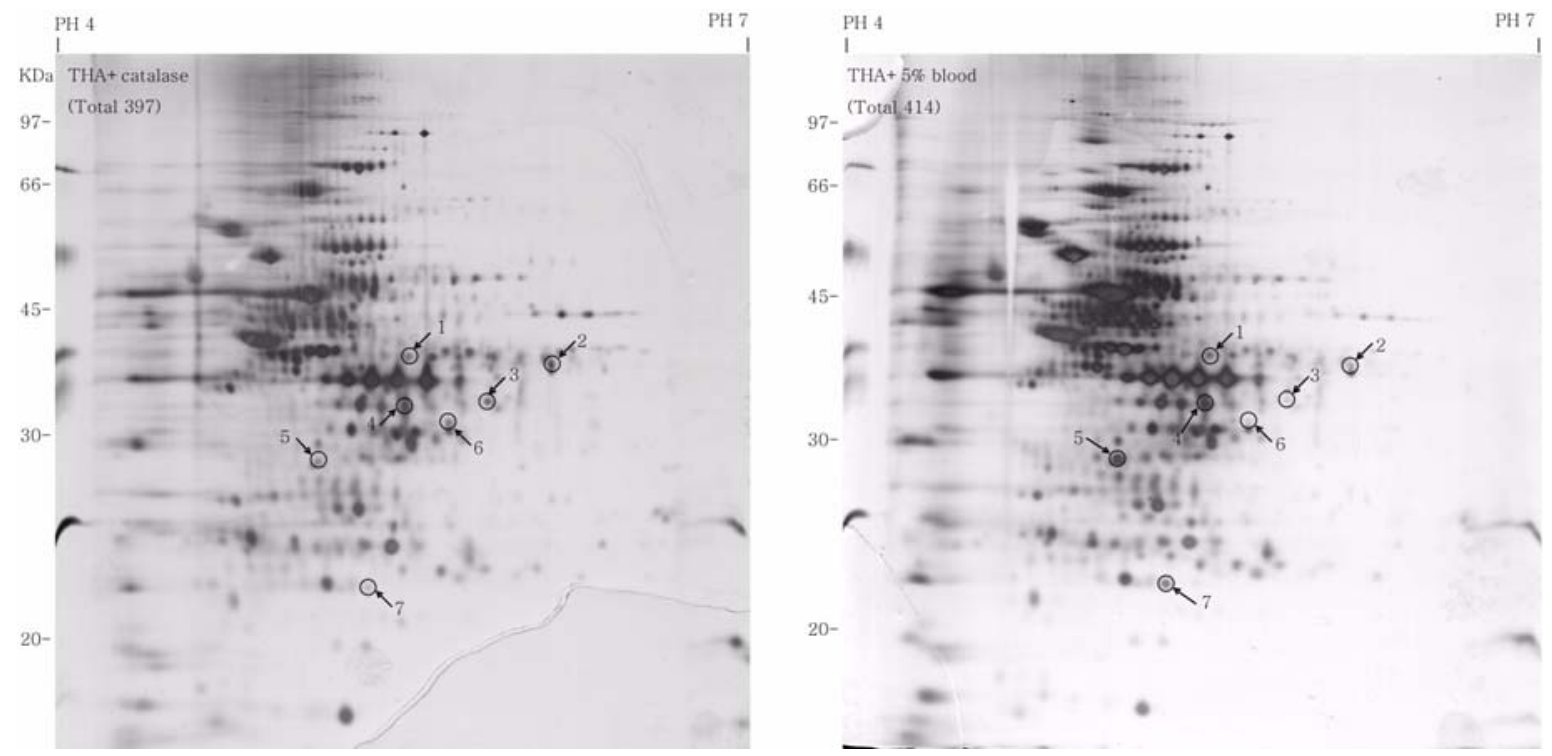

Fig. 2. Comparison of protein expression of $S$. pneumoniae D39 grown in THA containing without (A) and with 5\% sheep blood (B). Extracted proteins were separated by isoelectric focusing in the $\mathrm{p} I$ range of 4 to 7 in the first dimension $(18 \mathrm{~cm})$ and by $10 \%$ SDS-PAGE in the second dimension. Resolved proteins were visualized by silver staining. Spot numbers indicate proteins with altered expression.

\begin{tabular}{|c|c|c|c|}
\hline Spot No. & THA & THA $+5 \%$ blood & Fold change \\
\hline Spot 1. & & & 2.9 down \\
\hline Spot 2. & & 8 & 3.5 down \\
\hline Spot 3. & $\downarrow$ & $\downarrow$ & 8.0 up \\
\hline Spot 4. & & & 4.2 down \\
\hline Spot 5 . & & & 6.0 up \\
\hline Spot 6. & $\mathrm{~g}$ & - & 3.0 down \\
\hline Spot 7. & $\downarrow$ & $\downarrow$ & 3.4 up \\
\hline
\end{tabular}

Fig. 3. Comparison of selected protein spots with different abundance in THA and THA supplemented with blood.

Effect of blood on $S$. pneumoniae D39 protein expression. To investigate the effect of blood on $S$. pneumoniae protein expression, $S$. pneumoniae D39 was grown on the THA plate with or w/o blood at $37^{\circ} \mathrm{C}$ under $5 \% \mathrm{CO}_{2}$, respectively. Since the growth of $S$. pneumoniae, a catalase-deficient species, is inhibited under aerobic conditions, we added 5,000 $\mathrm{U}$ of catalase per THA plate without blood. The relative protein expression levels of $S$. pneumoniae D39 grown with or w/o blood were compared using two-dimensional protein gel electrophoresis followed by computerized comparison of the silver-stained gels. A total of 414 protein spots were observed when grown in THA plate supplemented with blood, and 397 spots were founded when grown on THA plate (Fig. 2). The results describe that $S$. pneumoniae alters its protein expression when exposed to blood, compared to growth without blood. Among the differentially expressed protein spots, we selected the most extensively changed seven protein spots: 3 proteins (Spot no. 4, 5, and 7) were increase by a factor of 3.4 times and 4 proteins (Spot no. 1, 2, 3, and 6) were down-regulated by a factor of at least 2.9 times in the presence of blood (Fig. 3).

Identification of differentially expressed proteins. The selected seven protein spots were identified using MALDITOF MS or LC-ESI MS/MS and MASCOT search program (Seong et al., 2002; Vandahl et al., 2004; Zhao et al., 2004). The identified seven proteins are summarized in Table 2. These included tyrosyl-tRNA synthetase, lactate oxidase, glutamyl-aminopeptidase, L-lactate dehydrogenase, cysteine synthase, ribose-phosphate pyrophosphokinase, and orotate phosphoribosyltransferase. These proteins involved in several cellular metabolisms such as protein biosynthesis, carbohydrate metabolism, and DNA/RNA synthesis, etc. 
Table 2. Identification of differentially expressed proteins

\begin{tabular}{|c|c|c|c|c|c|c|c|c|}
\hline Functional category & $\begin{array}{l}\text { Spot } \\
\text { no. }\end{array}$ & Identified protein & $\begin{array}{l}\text { Top } \\
\text { score }\end{array}$ & $\begin{array}{l}\text { Mached } \\
\text { peptides }\end{array}$ & $\begin{array}{c}\text { Sequence } \\
\text { coverage } \\
(\%)\end{array}$ & $\begin{array}{c}\mathrm{Mr} \\
(\mathrm{KDa})\end{array}$ & $\mathrm{p} I$ & Fold change \\
\hline $\begin{array}{l}\text { Aminoacyl tRNA synthetases and } \\
\text { their modification }\end{array}$ & 1 & Tyrosyl-tRNA synthetase & 99 & 10 & 29 & 47.5 & 5.46 & 2.9 down \\
\hline \multirow{2}{*}{ Central and intermediary metabolism } & 2 & Lactate oxidase & 75 & 7 & 35 & 41.6 & 5.77 & 3.5 down \\
\hline & 4 & L-lactate dehydrogenase & 73 & 6 & 24 & 35.3 & 5.09 & 4.2 up \\
\hline $\begin{array}{l}\text { Degradation of proteins, peptides } \\
\text { and glycoproteins }\end{array}$ & 3 & Glutamyl-aminopeptidase & 108 & 10 & 50 & 38.2 & 5.46 & 8.0 down \\
\hline Amino acid biosynthesis & 5 & Cysteine synthase & 120 & 9 & 33 & 31.9 & 4.96 & 6.0 up \\
\hline \multirow{2}{*}{$\begin{array}{l}\text { Purines, pyrimidines, nucelosides, } \\
\text { and nucleotides metabolisms }\end{array}$} & 6 & $\begin{array}{l}\text { Ribose-phosphate } \\
\text { pyrophosphokinase }\end{array}$ & 94 & 9 & 38 & 35.6 & 5.68 & 3.0 down \\
\hline & 7 & $\begin{array}{l}\text { Orotate } \\
\text { phosphoribosyltransferase }\end{array}$ & 74 & 6 & 31 & 22.8 & 5.07 & 3.4 up \\
\hline
\end{tabular}

\section{Discussion}

Streptococcus pneumoniae is a major respiratory pathogen of humans, causing pneumonia, septicemia, otitis media, and meningitis. This pathogen colonizes the mucosal surface of the nasopharynx and can spread into other sites such as bloodstream or lung tissues, resulting in the most serious forms of pneumococcal disease such as sepsis, meningitis, and pneumonia (Weiser et al., 2001). S. pneumoniae alters its protein expression in response to environmental changes which the bacteria encounter during infection.

In this study, the proteomic approach was used to assess the differences in $S$. pneumoniae protein expression between the growth in THY medium and THY supplemented with blood. We selected seven spots shown significant changes in spot intensity between the two conditions. The identified proteins are involved in various cellular metabolisms. Among them, the glutamyl-aminopeptidase dissolved proteins, peptides, and glycoproteins in order to use nutrients from the surroundings under nutrient-deficient conditions (Hoskins et al., 2001; Tettelin et al., 2001). Cysteine synthase is probably related both to homeostasis of the intracellular thiol-disulfide and to quick adaptation to sudden changes in the environment (Newton et al., 1996; Leichert et al., 2003).

Recently, Seki et al. (2004) reported lactate oxidase was responsible for $\mathrm{H}_{2} \mathrm{O}_{2}$ production in $S$. pyogenes during aerobic growth. In a number of species of lactic acid bacteria, it has been known that cells growing aerobically produce and excrete high amounts of $\mathrm{H}_{2} \mathrm{O}_{2}$. In $\mathrm{S}$. pneumoniae, in vitro and in vivo studies have suggested that endogenous $\mathrm{H}_{2} \mathrm{O}_{2}$ production may exceed $1 \mathrm{mM}$ in the surrounding media under aerobic growth, and act as a potential virulence factor by exerting direct damage to host tissues, as well as by inhibiting the growth of other respiratory tract flora (Hirst et al., 2000; Pericone et al., 2000). To date, it has been considered that pyruvate oxidase is the major enzyme responsible for $\mathrm{H}_{2} \mathrm{O}_{2}$ production in $S$. pneumoniae. The actual contribution of lactate oxidase for high levels of $\mathrm{H}_{2} \mathrm{O}_{2}$ by $\mathrm{S}$. pneumoniae remains unknown. Thus, further characterization of lactate oxidase may provide a foundation for evaluating the role in the physiology and pathogenesis of pneumococcus.

In conclusion, this global approach revealed that $S$. pneumoniae altered its metabolism when exposed to blood. The results can also provide a better understanding of $S$. pneumoniae adaptation to its human host and a clue for its pathogenicity.

\section{References}

Charpentier, E., Novak, R. and Tuomanen, E. (2000) Regulation of growth inhibition at high temperature, autolysis, transformation and adherence in Streptococcus pneumoniae by ClpC. Mol. Microbial. 37, 717-726.

Dinieal, M. M., Robert, F. B. and Alexander, T. (2000) Streptococcus pneumoniae: at the threshold of the 21st centry; Molecular Biology and Mechanism of Disease. Tomasz, A. (ed.), pp. 485-491, Mary Ann liebert, Inc., New York, USA.

Dowds, B. C. A. and Hoch, J. A. (1991) Regulation of the oxidative stress response by the hpr gene in Bacillus subtilis. $J$. Gen. Microbiol. 137, 1121-1125.

Herbert, B. R., Molly, M. P., Gooley, A. A., Walsh, B. J., Bryson, W. G. and Williams, K. L. (1998) Improved protein solubility in two-dimensional electrophoresis using tributyl phosphine as reducing agent. Electrophoresis 19, 845-851.

Heukeshoven, J. and Dernick, R. (1985) Increased sensitivity for coomassie staining of sodium dodecyl sulfate-polyacrylamide gels using phast system development unit. Electrophoresis 9, 60-61.

Hirst, R. A., Sikand, K. S., Rutman, A., Mitchell, T. J., Andrew, P. W. and O'Callaghan, C. (2000) Relative roles of pneumolysin and hydrogen peroxide from Streptococcus pneumoniae in inhibition of ependymal ciliary beat frequency. Infect. Immun. 68, $1557-1562$. 
Hoskins, J., Alborn, W. E., Arnold, J., Blaszczac, L.C., Burgett, S., DeHoff, B. S., Estrem, S. T, Fritz, L., Fu, D. J., Fuller, W., Geringer, C., Gilmour, R., Glass, J. S., Khoja, H., Kraft, A. R., Lagace, R. E., LeBlanc, D. J., Lee, L. N., Lefkowitz, E. J., Lu, J., Matsushima, P., McAhren, S. M., McHenney, M., McLeaster, K., Mundy, C. W., Nicas, T. I., Norris, F. H., O'Gara, M., Peery, R. B., Robertson, G. T., Rockey, P., Sun, P. M., Winkler, M. E., Yang, Y., Young-Bellido, M., Zhao, G., Zook, C. A., Baltz, R. H., Jaskunas, S. R., Rosteck, P. R., Skatrud, P. L. and Glass, J. I. (2001) Genome of the bacterium Streptococcus pneumoniae strain R6. J. Bacteriol. 183, 57095717.

Leichert, L. I., Scharf, C. and Hecker M. (2003) Global characterization of disulfide stress in Bacillus subtilis. $J$. Bacteriol. 185, 1967-1975.

Neuhoff, V., Arold, N., Taube, D. and Ehrhardt, W. (1988) Improved staining of proteins in polyacrylamide gels including isoelectric focusing gels with clear background at nanogram sensitivity using Coomassie Brilliant Blue G-250 and R-250. Electrophoresis 9, 255-262.

Newton, G. L., Arnold, K., Price, M. S., Sherrill, C., Delcardayre, S. B, Aharonowitz, Y., Cohen, G.., Davies, J., Fahey, R. C. and Davis, C. (1996) Distribution of thiols in microorganisms: mycothiol is a major thiol in most actinomycetes. J. Bacteriol. 178, 1990-1995.

Novak, R., Charpentier, E., Braun, J. S., Park, E., Murti, S., Tuomanen, E. and Masure, R. (2000) Extracellular targeting of choline-binding proteins in Streptococcus pneumoniae by a zinc metalloprotease. Mol. Microbiol. 36, 366-376.

Novak, R. and Tuomanen, E. (1999) Pathogenesis of pneumococcal pneumonia. Semin. Respir. Infect. 14, 209-217.

Pericone, C. D., overweg, K., Hermans, W. M. and Weiser, J. N. (2000) Inhibitory and bactericidal effect of Streptococcus pneumoniae on other inhabitants of the upper respiratory tract. Infect. Immun. 68, 3990-3997.

Rabilloud, T. (1996) Solubilization of proteins for electrophoretic analyses. Electrophoresis 17, 813-829.

Schuchat, A., Robinson, K., Wenger, J. D., Harrison, L. H., Farley, M., Reingold, A. L., Lefkowitz, L. and Perkins, B. A. (1997)
Bacterial meningitis in the United States in 1995. N. Engl. J. med. 337, 970-976.

Seki, M., Iida, K. I., Saito, M., Nakayama, H. and Yoshida, S. I. (2004) Hydrogen peroxide production in Streptococcus pyogenes: involvement of lactate oxidase and coupling with aerobic utilization of lactate. J. Bacteriol. 186, 2046-2051.

Seong, J. K., Kim, D. K., Choi, K. H., Oh, S. H., Kim, K. S., Lee, S. S. and Um, H. D. (2002) Proteomic analysis of the cellular proteins induced by adaptive concentrations of hydrogen peroxide in human U937 cells. Exp. Mol. Med. 34, 374-378.

Tettelin, H., Nelson, K. Fl., Paulsen, I. T., Eisen, J. A., Read, T. D., Peterson, S., Heidelberg, J., DeBoy, R. T., Haft, D. H., Dodson, R. J., Durkin, A. S., Gwinn, M., Kolonay, J. F., Nelson, W. C., Peterson, J. D., Umayam, L. A., White, O., Salzberg, S. L., Lewis, M. R., Radune, D., Holtzapple, E., Khouri, H., Wolf, A. M., Utterback, T. R., Hansen, C. L., McDonald, L. A., Feldblyum, T. V., Angiuoli, S., Dickinson, T., Hickey, E. K., Holt, I. E., Loftus, B. J., Yang, F., Smith, H. O., Venter, J. C., Dougherty, B. A., Morrison, D. A., Hollingshead, S. K. and Fraser, C. M. (2001) Complete genome sequence of a virulent isolate of Streptococcus pneumoniae. Science 293, 498-506.

Tuomanen, E. (1999) Molecular and biology of pneumococcal infection. Curr. Opin. Microbial. 2, 35-39.

Vandahl, B. B. S., Birkelund, S. and Christiansen, G. (2004) Genome and proteome analysis of Chlamydia. Proteomics 4, 2831-2842.

Weiser, J. N., Bae, D., Epino, H., Gordon, S. B., Kapoor, M., Zenewicz, L. A. and Shchepetov, M. (2001) Changes in availability of oxygen accentuate differences in capsular polysaccharide expression by phenotypic variants and clinical isolates of Streptococcus pneumoniae. Infect. Immun. 69, 54305439.

Zhao, B., Yeo, C. C., Lee, C. C., Geng, A., Chew, F. T. and Poh, C. L. (2004) Proteome analysis of gentisate-induced response in Pseudomonas alcaligenes NCIB9867. Proteomics 4, 20282036. 